\title{
A Headspace Solid Phase Microextraction (HS-SPME) Method for the Chromatographic Determination of Alkylpyrazines in Cocoa Samples
}

\author{
Gláucia F. Pini ${ }^{a}$, Edy S. de Brito ${ }^{b}$, Nelson H.P. García ${ }^{b}$,Antonio L. P. Valente ${ }^{\dagger}, a$ and Fabio Augusto ${ }^{*, a}$ \\ ${ }^{a}$ Instituto de Química and ${ }^{b}$ Faculdade de Engenharia de Alimentos, Universidade Estadual de Campinas, \\ CP 6154, 13084-971 Campinas - SP, Brazil
}

\begin{abstract}
Um procedimento de Microextração em Fase Sólida em Headspace (HS-SPME) para isolamento e determinação de alquilpirazinas em liquor de cacau, usando Cromatografia Gasosa com Detecção por Ionização em Chama (GC-FID) é apresentado aqui. As condições operacionais de HS-SPME foram otimizadas usando extrações de amostras fortificadas com quantidades conhecidas de alquilpirazinas tipicamente encontradas em derivados de cacau. A eficiência máxima de extração foi obtida com fibras de SPME recobertas com $65 \mu \mathrm{m}$ de Carbowax/divinilbenzeno. Em adição, os melhores resultados foram obtidos usando $60^{\circ} \mathrm{C}$ como temperatura de extração, 15 min como tempo de equilíbrio amostra/headspace e 45 min como tempo de extração. Observou-se também que o uso de solução aquosa saturada de $\mathrm{NaCl}$ para suspender as amostras durante as extrações resultou em um incremento significativo nas áreas dos picos. Este procedimento se mostrou efetivo para a determinação das razões pirazínicas (quocientes entre as áreas dos picos de alquilpirazinas), que são úteis como parâmetros de qualidade para liquor de cacau.
\end{abstract}

A Headspace Solid Phase Microextraction (HS-SPME) procedure for isolation and determination of alkylpyrazines in cocoa liquor, using Gas Chromatography with Flame Ionization Detection (GCFID) for the separation and detection of the analytes, is presented here. The HS-SPME operational conditions were optimized using extractions of samples spiked with known amounts of alkylpyrazines typically found on cocoa products. The maximum extraction efficiency was obtained using SPME fibers coated with $65 \mu \mathrm{m}$ Carbowax/divinylbenzene. Additionally, the best results were achieved with extraction temperature of $60^{\circ} \mathrm{C}, 15 \mathrm{~min}$ of sample/headspace equilibration time and $45 \mathrm{~min}$ extraction time. It was also observed that suspending the samples in saturated aqueous $\mathrm{NaCl}$ solution during extractions resulted in a significant increment on the peak areas. This procedure was found to be effective to determine the so-called pyrazinic ratios (quotient between peak areas of alkylpyrazines), which are useful as quality parameters for cocoa liquor.

Keywords: cocoa liquor, alkylpyrazines, aroma, Maillard reaction products, SPME

\section{Introduction}

The processing of cocoa seeds (Theobroma cacao, L. $)^{1}$ comprises their drying, fermentation of sugars contained in the pulp covering the seeds, roasting, separation and grounding of the roasted nibs. The resulting fatty solid product (known as cocoa liquor) is the base raw material for chocolate industry. The most significant flavor-impact substances on cocoa derivatives are $\mathrm{N}$ - and O-containing heterocyclic compounds generated during the roasting, which are products of the complex sequence of heatinduced chemical processes collectively known as

\footnotetext{
* e-mail: augusto@iqm.unicamp.br

$\dagger$ in memoriam $(1944-2002)$
}

Maillard reactions. ${ }^{2}$ The substrates for the Maillard reactions are reducing sugars, small peptides, aminoacids and / or triglycerides contained in the raw, unroasted material. For cocoa, in terms of contribution to their sensorial characteristics (and, in consequence, to their commercial value), the most important Maillard reaction products are the alkylpyrazines. ${ }^{3}$ Considering their impact on the aroma, the ratios between the amounts of some alkylpyrazines on the volatile fraction of of cocoa and chocolate (the pyrazinic ratios) can be adopted as parameter for quality assessment of these products. ${ }^{4}$

The determination of alkylpyrazines on cocoa products has been performed using techniques such as vacuum distillation, ${ }^{5}$ simultaneous distillation / extraction (Lickens-Nickerson technique), ${ }^{3}$ continuous liquid-solid 
extraction $^{6}$ or supercritical fluid extraction 7 for analyte isolation and pre-concentration, always followed by separation and detection of extracted materials by Gas Chromatography (GC). However, some of these techniques demand intensive heating of the samples, which can generate additional amounts of alkylpyrazines by interaction between Maillard substrates still present on the matrixes and, in consequence, result on overestimated figures for the concentrations of these species. It has been reported that this can happen at temperatures as low as $70{ }^{\circ} \mathrm{C} .{ }^{8}$ As for the solvent extraction methods, their application to such samples can not be regarded as convenient. The high content on lipids, alkaloids, polyphenols, sugar and other non-volatile and potentially extractable substances in the matrix ${ }^{9}$ can result in dirty, complex extracts which may not be fully compatible with GC. Considering the limitations of these sample preparation techniques, Headspace Solid Phase Microextraction (HS-SPME) - a relatively fast, simple and solvent-less extraction and pre-concentration strategy ${ }^{10}$ - can be an interesting alternative for isolation and chromatographic analysis of alkylpyrazines in cocoa derivatives. The sample manipulation needed in SPME, which is reduced when compared to other related techniques, makes it particularly useful for application to problems involving chemically or thermally unstable analytes or in cases where generation of artifacts can be a problem, ${ }^{11}$ such as the present case.

In this work an HS-SPME-GC-FID analytical procedure was developed for the determination of alkylpyrazines in samples of Brazilian cocoa liquor. Since samples of cocoa products with certified concentrations of alkylpyrazines are not available, the HS-SMPE sample preparation procedure was optimized using fortified cocoa liquor samples supplied by the Laboratory of Process Development of the Food Engineering Department of our University. The results of the present study were used as part of the experimental information on the optimization of the processing of Brazilian cocoa nibs. ${ }^{12}$

\section{Experimental}

\section{Materials}

Samples. Fermented cocoa beans (Forastero variety) were obtained from the Campinas Agricultural Institute Experimental Station of Pariquera-Açú, São Paulo, Brazil. The beans were broken into nibs (3-6 mm), roasted for $38 \mathrm{~min}$ at $150^{\circ} \mathrm{C}$ in a PRE $1 \mathrm{Z}$ sample roaster (Probat-Werke, Emmerich, Germany) and ground in an IKA A10 analytical mill (Janke \& Kunkel, Staufen, Germany). This singleroasted cocoa liquor was kept on sealed glass vials under refrigeration $\left(-12^{\circ} \mathrm{C}\right)$ until use, and employed as test sample for the optimization of the SPME method. After optimization, the SPME method was applied to the determination of pyrazinic ratios of materials processed using three different procedures: single-roasted liquor $(R$ samples), autoclaved liquor ( $A$ samples: single-roasted liquor submitted to additional autoclaving for $15 \mathrm{~min}$ at $121^{\circ} \mathrm{C}$ ) and autoclaved/roasted liquor ( $A R$ samples: samples similar to $A$ but submitted to 38 min of additional roasting at $150{ }^{\circ} \mathrm{C}$ after autoclaving).

Chemicals. Analytical grade pyrazine, 2-methylpyrazine, 2,3-dimethylpirazine, 2,5-dimethylpirazine, 2,6dimethylpirazine, ethylpyrazine, trimethylpyrazine and tetramethylpyrazine (Aldrich, Milwaukee, WI) were employed.

Extraction. SPME fibers (Supelco, Bellefonte, PA) coated with $100 \mu \mathrm{m}$ polydimethylsiloxane (PDMS), $65 \mu \mathrm{m}$ Carbowax/divinylbenzene (CWX) and $85 \mu \mathrm{m}$ polyacrylate (PA) were tested. Prior to use the fibers were conditioned according to the supplier instructions. All extractions were performed in $15 \mathrm{ml}$ septum-sealed glass V-vials (Wheaton, Millville, NJ) under agitation with Teflon-coated magnetic stirring bars.

Gas Chromatograph. An AutoSystem XL (Perkin Elmer Co, Norwalk, CT, USA) gas chromatograph fitted with a FID and a $30 \mathrm{~m} \times 0.53 \mathrm{~mm} \times 0.5 \mu \mathrm{m}$ PE-WAX capillary column (Perkin Elmer) was used through all the work. The GC oven temperature was programmed as follows: $10 \mathrm{~min}$ at $45^{\circ} \mathrm{C}$, then heating at $10^{\circ} \mathrm{C} \min ^{-1}$ up to $295^{\circ} \mathrm{C}$ and held for $5 \mathrm{~min}$. Helium $\left(25 \mathrm{~mL} \mathrm{~min}^{-1}\right)$ was the carrier gas. The temperature of the injector (operated on splitless mode) and of the detector was $240{ }^{\circ} \mathrm{C}$; the SPME fiber desorption time was $4 \mathrm{~min}$. Under these conditions, no sample carryover was observed on blank runs conducted between extractions.

\section{Optimization of the HS-SPME method}

Extraction time and fiber coating. A suspension of (1.00 $\pm 0.05) \mathrm{g}$ of single-roasted liquor in $10 \mathrm{~mL}$ of distilled water was enclosed in a V-vial and spiked with $100 \mathrm{mg}$ of each alkylpyrazine listed in Materials/Chemicals. The suspension was magnetically stirred for $15 \mathrm{~min}$ for sample/ headspace equilibration. Then, a SPME fiber (CWX, PA or PDMS) was exposed to the headspace for periods of time ranging from $5 \mathrm{~min}$ to $81 \mathrm{~min}$, and the extracted analytes immediately chromatographed. Temperature was kept at $60{ }^{\circ} \mathrm{C}$ during all sample / headspace equilibration and extraction, which was performed in triplicate.

Extraction temperature and sample / headspace equilibration time. A similar procedure was employed, 
using 45 min of extraction with CWX fibers, 15 min sample/ headspace equilibration time but with the operational temperature ranging from $20^{\circ} \mathrm{C}$ to $73^{\circ} \mathrm{C}$. For the determination of sample / headspace equilibration time, this parameter was ranged from $5 \mathrm{~min}$ to $60 \mathrm{~min}$ and temperature was fixed at $60^{\circ} \mathrm{C}$.

Effect of ionic strength. Experiments replacing the distilled water as sample suspension media with aqueous $\mathrm{NaCl}$ solution with concentrations ranging from $35 \mathrm{~g} \mathrm{~L}^{-1}$ to $353 \mathrm{~g} \mathrm{~L}^{-1}$ (saturated solution) were conducted. CWX fibers were used for all experiments, with temperature of $60{ }^{\circ} \mathrm{C}$, extraction time of $60 \mathrm{~min}$ and sample/headspace equilibration time of $15 \mathrm{~min}$.

\section{Determination of pyrazinic ratios in $R, A$ and $A R$ cocoa} samples

A suspension of $(1.00 \pm 0.05) \mathrm{g}$ of cocoa liquor in $10 \mathrm{~mL}$ of saturated aqueous $\mathrm{NaCl}$ solution containing $10 \mu \mathrm{g} \mathrm{mL}^{-1}$ of pyrazine (internal standard) was stirred for $15 \mathrm{~min}$ at $60^{\circ} \mathrm{C}$ for sample / headspace equilibration and then a CWX fiber exposed to the headspace for $45 \mathrm{~min}$. The extracted analytes were immediately desorbed and chromatographed. The pyrazinic ratios were calculated as the quotients between the peak areas of trimethylpyrazine and tetramethylpyrazine.

\section{Results and Discussion}

For the studied alkylpyranizes the maximum extraction efficiency was obtained with CWX fiber (Figure 1), which was selected for the continuation of the work. This is

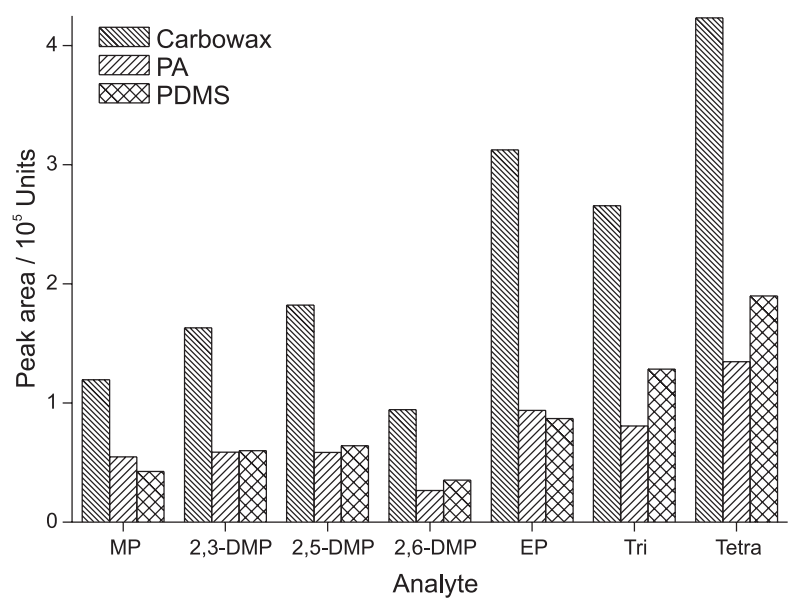

Figure 1. Peak areas for alkylpyrazines $(\mathrm{MP}=$ methylpyrazine; 2,3DMP, 2,5-DMP and 2,6-DMP: dimetylpyrazines; EP = ethylpyrazine; Tri $=$ trimethylpyrazine and Tetra $=$ tetramethylpyrazine) after 60 min HS extraction with $65 \mu \mathrm{m}$ Carbowax/DVB, $85 \mu \mathrm{m}$ polyacrylate (PA) and $100 \mu \mathrm{m}$ PDMS fibers. consistent with the chemical properties of the analytes and fiber coatings being studied: CWX is a polar sorbent phase (polyglycol), which is expected to have higher affinity towards polar species such as the alkylpyrazines when compared to moderately polar (PA) or non-polar (PDMS) coatings. ${ }^{13}$

Figure 2 shows the peak area versus extraction time profiles for trimethylpyrazine, tetramethylpyrazine and 2,5-dimethylpyrazine (which is representative of the behavior of 2-methylpyrazine, ethylpyrazine and of the dimethylpyrazines). It can be seen that for 2,5dimethylpyrazine, equilibrium is attained after circa 30 min. For tri- and tetramethylpyrazine, equilibrium was not reached. However, considering the standard deviation of the data, the increase on the peak areas for these analytes after 45 min extraction can be considered as not significant. Also, the increment on the standard deviation of the average areas for $60 \mathrm{~min}$ extraction shows that there is a degeneration on the method precision for longer extraction times. Therefore, the extraction time was fixed in $45 \mathrm{~min}$.

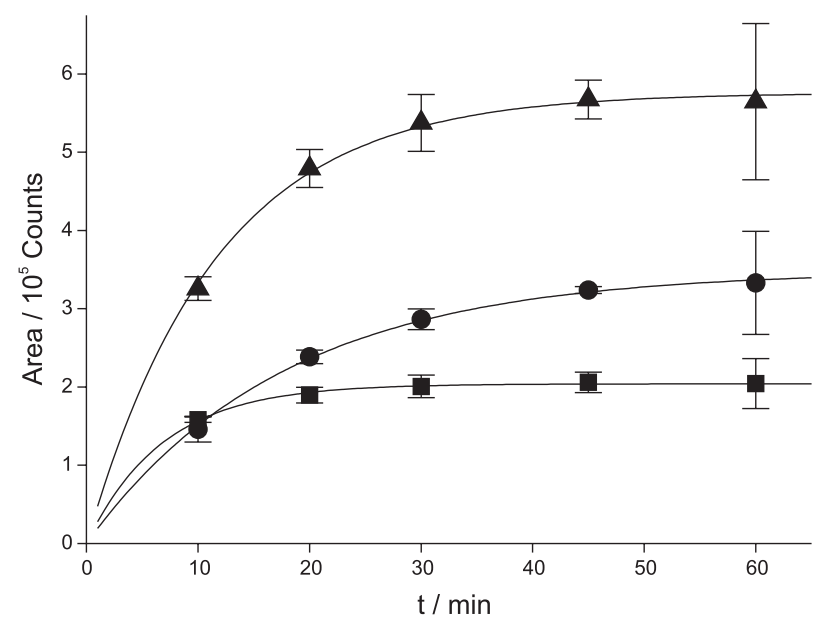

Figure 2. Peak area versus extraction time profiles obtained with 65 $\mathrm{mm}$ Carbowax/DVB fiber for 2,5-dimethylpyrazine (ם), trimethylpyrazine $(\bullet)$ and tetramethylpyrazine $(\mathbf{\Delta})$. Error bars are the standard deviation of the triplicate measurements.

As to the sample / headspace equilibration time, it has been observed that the extraction efficiency remained constant in the range of $5 \mathrm{~min}$ to up to $45 \mathrm{~min}$ of equilibration time. The sample / headspace equilibration time of 15 min was used in all experiments envisaging to shorten the overall analysis time as well as to ensure a proper stirring of the non-homogeneous mixture of cocoa liquor and aqueous phase.

Figure 3 depicts the variation the peak areas with the extraction temperature for 2,3-dimethylpyrazine, 2,6dimethylpyrazine, trimethylpyrazine and tetramethyl- 
pyrazine; similar behaviors were observed for the other alkylpyrazines. The most remarkable feature of the curves is the sharp increase in the extracted amounts of the dimethylpyrazines in the range between $61^{\circ} \mathrm{C}$ and $73^{\circ} \mathrm{C}$. This is an evidence that for temperatures higher than $60^{\circ} \mathrm{C}$, Maillard reactions start to occur between residual substractes in the samples. Therefore, the increase on the extracted amounts can not be related to an higher extraction efficiency but to the generation of analytes not originally present in the samples. Additionally, in the same temperature range the extracted amount of tetramethylpyrazine decreases. In view of these results all HS-SMPE extractions were undertaken at the temperature of $60^{\circ} \mathrm{C}$.

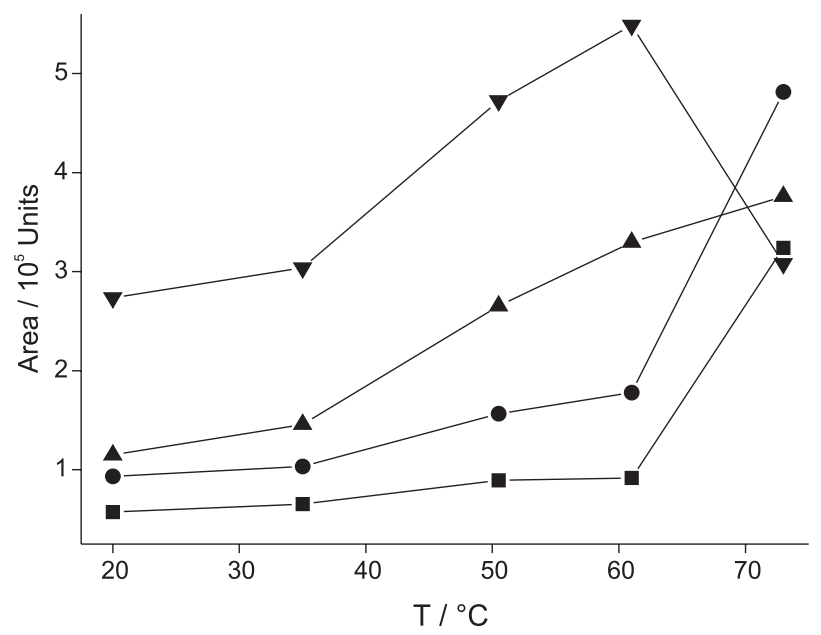

Figure 3. Peak area as function of temperature for 2,6dimethylpyrazine $(\square)$, 2,3-dimethylpyrazine $(\boldsymbol{O})$, trimethylpyrazine (A) and tetramethylpyrazine $(\boldsymbol{\nabla})$.

To study the effect of the ionic strength on the extraction efficiency, for each alkylpyrazine the peak areas obtained after extractions of samples suspended on aqueous $\mathrm{NaCl}$ solutions with concentrations up to $353 \mathrm{~g} \mathrm{~L}^{-1}$ were compared to the areas for extractions using the same samples suspended on pure water. The increment on peak areas (in \%) resulting from the use of saline solutions to suspend the samples is depicted on Figure 4.

As can be seen in Figure 4 the increment of the $\mathrm{NaCl}$ concentration in the cocoa liquor-water mixture results in an improvement on the HS-SPME extraction efficiency for the seven pyrazines. Due to these results all extractions were conducted suspending the samples with the saturated $\mathrm{NaCl}$ solution $\left(353 \mathrm{~g} \mathrm{~L}^{-1}\right)$.

Figure 5 depicts a typical chromatogram of the cocoa liquor.

The method was applied to assess the differences between cocoa samples processed using different roasting

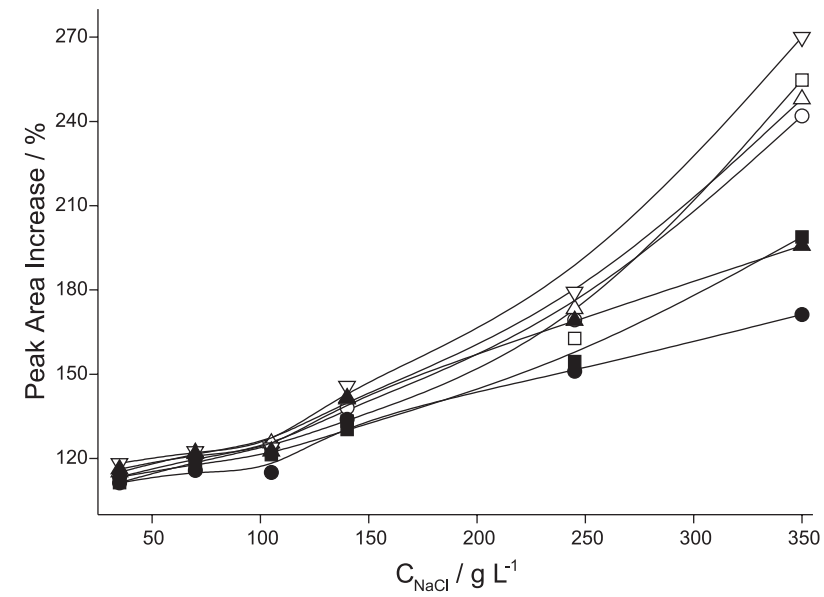

Figure 4. Increase on the peak areas as function of $\mathrm{NaCl}$ concentration on the extracting media for 2-methylpyrazine ( $\square)$, 2,3dimethylpyrazine $(\bigcirc), 2,5$-dimethylpyrazine $(\triangle), 2,6$ dimethylpyrazine $(\nabla)$, 2-ethylpyrazine $(\square)$, trimethylpyrazine $(\mathbf{O})$ and tetramethylpyrazine $(\mathbf{\Delta})$.

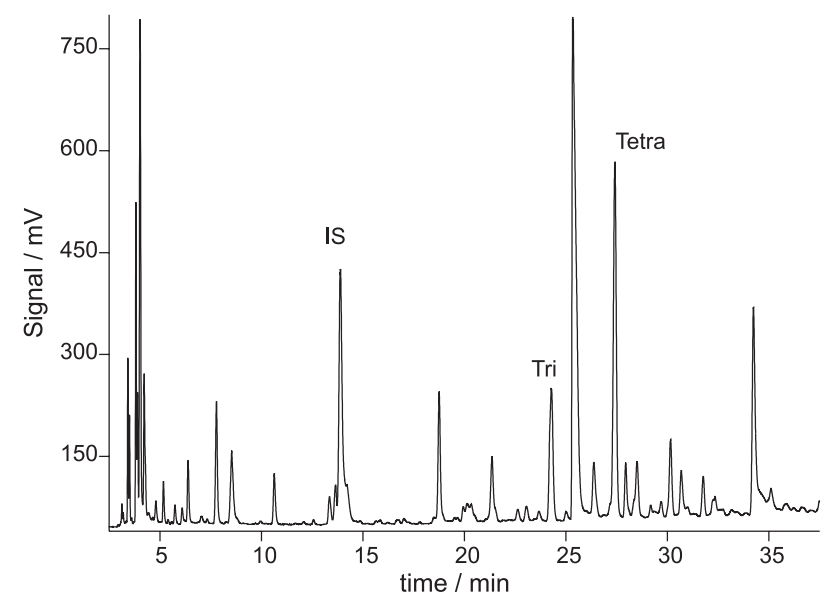

Figure 5. Typical HS-SPME chromatogram of cocoa liquor. Peak assignment: IS = pyrazine (internal standard); Tri = trimethylpyrazine and Tetra $=$ tetramethylpyrazine.

strategies. ${ }^{12}$ In all chromatograms it was possible to identify, spiking the samples with authentic standards, two of the target analytes: trimethylpyrazine and tetramethylpyrazine. The pyrazinic ratios for the $\mathrm{R}, \mathrm{A}$ and AR cocoa liquor samples produce through different procedures, as described before, were: $\mathrm{R}=31.3 ; \mathrm{A}=11.1$ and $\mathrm{AR}=2.2$. The decrease of the value on this pyrazinic ratio ${ }^{14}$ is regarded to be indicative of improvement of the cocoa nib processing, which is in agreement with the behavior of other parameters evaluated for these samples such as the content on glucose and extractable aminoacids. These observations strongly suggest that the procedure here proposed is an appropriate tool for the assessment of the sensory quality of cocoa derivatives. 


\section{Conclusions}

The assessment of control parameters that may be used as tool for the monitoring and improvement of the processing of cocoa is a relevant task. It may be concluded that the GC analysis of pyrazines in cocoa samples allows the establishment of the pyrazinic ratio, which is an appropriate parameter because it is focused on the relative amount of individually detected target analytes. The optimization of the HS-SPME described in this work has shown that this sample preparation technique may be conveniently applied to the cocoa samples to assess pyrazinic ratios useful for evaluation of sample quality.

\section{Acknowledgments}

The authors whish to thank FAPESP and CNPq for the support to this work.

\section{References}

1. Wieland, H.; Chocolate and Cocoa Processing, Noyes: Park Ridge, 1972, ch. 1

2. Vernin G.; Parkányi C. In Chemistry of Heterocyclic Compounds in Flavours and Aromas; Vernin, G., ed.; Ellis Horwood: Chichester, 1982.

3. Bonvehí, J.S.; Coll, F.V.; J. Agric. Food Chem. 2002, 50, 3743.
4. van de Wal, B.; Kettenes, D. K.; Stoffelsma, J.; Sipma, G.; Semper, A. T. J.; J. Agric. Food Chem. 1971, 19, 276.

5. Counet, C.; Callemien, D.; Ouwerx, C.; Collin, S.; J. Agric. Food Chem. 2002, 50, 2385.

6. Schnermann, P.; Schieberle, P.; J. Agric. Food Chem. 1997, 45, 867.

7. Sanagi, M.M.; Hung, W.P.; Yasir, S.M.; J. Chromatogr. A 1997 , 785,361 .

8. Reineccius, G.A.; Keeney, P. G.; Weisberger, W.; J. Agric. Food Chem. 1972, 20, 202.

9. Luna, F.; Crouzillat, D.; Loïc, C.; Bucheli, P.; J. Agric. Food Chem. 2002, 50, 3527.

10. Pawliszin, J. In Applications of Solid Phase Microextraction; Pawliszin, J., ed.; RSC Chromatography Monographs: Cambridge, UK, 1999, ch. 1.

11. Sides, A.; Robards, K.; Helliwell, S.; TrAC Trends Anal. Chem 2000, 19, 322.

12. Brito, E.S.; García, N.H.P.; Amancio, A.C.; Valente, A.L.P.; Pini, G.F.; Augusto, F.; Int. J. Food Sci. Technol. 2001, 36, 625 .

13. Mani, V. In Applications of Solid Phase Microextraction; Pawliszin, J., ed.; RSC Chromatography Monographs: Cambridge, UK, 1999, ch. 5.

14. Hashim, L.; Chaveron, H.; Food Res. Int. 1994, 27, 537.

Received: October 21, 2002

Published on the web: March 30, 2004

FAPESP helped in meeting the publication costs of this article. 